\title{
BY520-9, A Peach Rootstock for the Southeastern United States that Increases Scion Longevity
}

\author{
W.R. Okie, T.G. Beckman, and A.P. Nyczepir \\ Southeastern Fruit and Tree Nut Research Laboratory, U.S. Department of \\ Agriculture, 111 Dunbar Road, Byron, GA 31008
}

\section{G. L. Reighard', W.C. Newall, Jr.', and E.I. Zehr² Clemson University, Clemson, SC 29634}

Additional index words. Prunus persica, Meloidogyne, Criconemella, peach tree short life

BY520-9 is being provisionally released as bulk seed for industry testing as a rootstock for peach and nectarine [Prunus persica (L.) Batsch] where root-knot nematode (Meloidogyne spp.), peach tree short life (PTSL) associated with ring nematode (Criconemella xenoplax (Raski) Luc \& Raski], or both are a problem. BY520-9 consists of open-pollinated seed of 69 selections from B594520-9, which traces back to S-37 and Nemaguard.

\section{Origin}

One of the early goals of U.S. Dept. of Agriculture (USDA) stone-fruit breeding programs in Fort Valley, Ga.; Belts-vine, Md.; and Fresno, Calif., was the development of a well-adapted, root-knot-nematode-resistant peach rootstock. BY520-9 lineage traces to a 1954 cross made by J. Weinberger at Fort Valley of FV235-4 × FV234-1 (Fig. 1). FV235-4 was an open-pollinated seedling of S-37, itself a seedling of an unknown flowering peach. S-37 was used in California because of its resistance to $M$. incognita (Kofoid and White) Chitwood (Lownsbemy et al., 1959) and high vigor, but has fallen into disuse. S-37 apparently segregates for nectarine, weeping habit, and white flowers (Werner et al., 1985), but clonal material was unavailable for testing. FV234-1 was released in 1959 for testing and, in 1961, was named Nemaguard for its resistance to. both $M$. incognita and $M$. javanica (Treub) Chitwood (Lownsberry et al., 1959). It is still used widely in California and elsewhere.

From seed of Weinberger's cross planted at Fresno in 1955, seedling F51-25 was selected. Seedlings of F51-25 were found by H.W. Fogle and J.M. Good to be resistant to root-knot nematode in tests at the USDA in Beltsville, and subsequently planted in the field under the designations B594503B594538. Seedlings of these plants were later

Received for publication 26 May 1993. Accepted forpublication27Sept.1993, The cost ofpublishing this paper was defrayed in part by the payment of page charges. Under postal regulations, this paper therefore must be hereby marked advertisement solely to indicate this fact.

'Dept. of Horticulture.

${ }^{2}$ Dept. of Plant Pathology. screened and found uniformly resistant to $M$. incognita and M.javanica (unpublished data). Seedlings of B594520 were sent to Byron, $\mathrm{Ga}$., where the Fort Valley breeding program now resides. V.E. Prince planted the seedlings along with other material in 1968.

At that time, there was an effort in Georgia to find a rootstock to provide longer tree life where PTSL was a problem. Scion cultivars on seedling rootstock of Nemaguard, and other root-knot-resistant seedlings from Yunnan, S-37, and Shalil were much shorter-lived than scions on Lovell (root-knot-susceptible) seedling rootstock (Ritchie and Clayton, 1981). PTSL was later shown to be associated with parasitism by the ring nematode (C. xenoplax) (Nyczepir et al., 1983).

Seedlings of this rootstock material were evaluated in the greenhouse at Byron for reaction to ring and root-knot nematodes by E.J. Wehunt. Selected accessions, including three seedlings of B594520 (-3, -8, and -9), were repropagated as budded trees by $\mathrm{S}$. Doud and U.L. Yadava of Fort Valley State College in 197677. After 1979, the block was maintained by the USDA and was the source of much of the

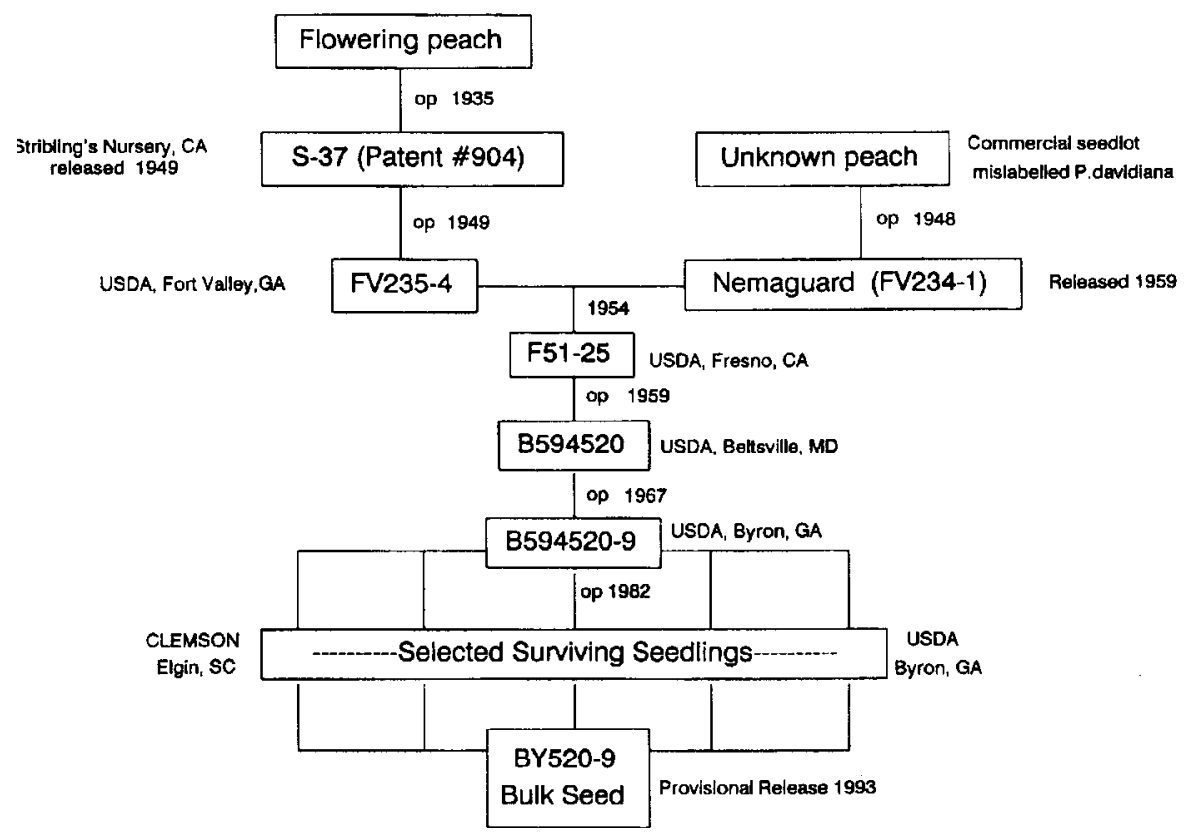

Fig. 1. Pedigree of BY520-9 rootstock. Open-pollinated generations designated "op." vived well after 8 or 9 years of field screening seed tested in South Carolina and Georgia (Okie et al., 1994) in a ITSL field screen. These trees were eventually removed, including the only trees of B594520-9. Seedlings of B594520-9 that were survivors of the PTSL field screen are the source of the bulk seed being released under the designation BY520-9.

The longevity of B594520-9 and BY520-9 is surprising in light of the limited longevity of their ancestors. Possibly, one of the openpollinated generations involved an outcross that improved survivability. High levels of resistance to $M$. javanica in B594520 apparently came from Nemaguard.

\section{Description}

The 69 individual selections making up BY520-9 vary in morphological characteristics. Most are peaches with pink flowers. About one-third are nectarines, while one-sixth are white-flowered. All have large, showy flowers with a chilling requirement of $\approx 850 \mathrm{~h}$ below 7C. Leaves on all selections have reniform glands. All have poor-quality, whitefleshed freestone fruit that ripens several weeks after 'Elberta'.

As rootstock, seedlings of these BY520-9 parental selections cause the scion to be less susceptible to cold injury and bacterial canker (Pseudomonas syringae pv syringae vanHall), the principal causes of PTSL death (Ritchie and Clayton, 198 1), than any other rootstock tested so far in the southeastern United States. Preliminary trials show root-knot-nematode resistance comparable to seedlings of Nemaguard and excellent tree vigor. No graft incompatibility with peach has been detected in limited trials so far using 'Cresthaven', 'Redhaven', and 'Springcrest' scions.

\section{Performance}

Unbudded seedlings of B594520-9 sur- 
Table 1. Survival of B594520-9 seedlings (=BY520-9) compared to seedlings of standard rootstocks after 8 years at Elgin, S.C., and 9 years at Byron, Ga. Losses shown due to peach tree short life (PTSL) and Clitocybe root rot (ROT).

\begin{tabular}{|c|c|c|c|c|c|c|c|}
\hline \multirow[b]{2}{*}{ Rootstock } & \multicolumn{3}{|c|}{ Elgin } & \multicolumn{4}{|c|}{ Byron } \\
\hline & n & Alive (\%) & PTSL (\%) & $\mathrm{n}$ & Alive (\%) & ROT (\%) & PTSL (\%) \\
\hline B594520-9 & 40 & 93 & 7 & 48 & 56 & 33 & 11 \\
\hline Lovell & 47 & 60 & 40 & 48 & 25 & 27 & 48 \\
\hline Halford & 49 & 47 & 53 & 49 & 22 & 43 & 35 \\
\hline Nemaguard & 46 & 26 & 74 & 49 & 14 & 35 & 51 \\
\hline Siberian C & 51 & 10 & 90 & 48 & 0 & 58 & 42 \\
\hline
\end{tabular}

Table 2. Survival, mean bacterial canker (BC) rating, and mean trunk cross-sectional area (TCSA) of 'Springcrest' and 'Redhaven' peach scions budded on seedling rootstocks of BY520-9 in comparison to seedlings of standards Lovell and Nemaguard after 4 years at Elgin, S.C., and Byron, Ga.

\begin{tabular}{|c|c|c|c|c|c|c|c|c|c|c|c|c|}
\hline \multirow[b]{3}{*}{ Rootstock } & \multicolumn{8}{|c|}{ Eglin } & \multirow{2}{*}{\multicolumn{4}{|c|}{$\begin{array}{c}\text { Byron } \\
\text { Redhaven }\end{array}$}} \\
\hline & \multicolumn{4}{|c|}{ Springcrest } & \multicolumn{4}{|c|}{ Redhaven } & & & & \\
\hline & $\mathrm{n}$ & $\begin{array}{c}\text { Alive }^{z} \\
(\%)\end{array}$ & $\mathrm{BC}^{\mathrm{y}}$ & $\begin{array}{l}\text { TCSA } \\
\left(\mathrm{cm}^{2}\right)\end{array}$ & $\mathrm{n}$ & $\begin{array}{l}\text { Alive } \\
(\%)\end{array}$ & $\mathrm{BC}$ & $\begin{array}{l}\text { TCSA } \\
\left(\mathrm{cm}^{2}\right)\end{array}$ & $\mathrm{n}$ & $\begin{array}{c}\text { Alive } \\
(\%)\end{array}$ & $\mathrm{BC}$ & $\begin{array}{l}\text { TCSA } \\
\left(\mathrm{cm}^{2}\right)\end{array}$ \\
\hline$\overline{\text { BY520-9 }}$ & 13 & $100 \mathrm{a}$ & 0.2 & 98 & 20 & $100 \mathrm{a}$ & 0.0 & 88 & 10 & $100 a$ & 0.5 & 59 \\
\hline Lovell & 15 & $67 \mathrm{~b}$ & 2.3 & 67 & 20 & $65 \mathrm{~b}$ & 2.1 & 48 & 10 & $100 \mathrm{a}$ & 0.0 & 45 \\
\hline Nemaguard & 19 & $5 \mathrm{c}$ & 4.8 & 107 & 19 & $21 \mathrm{c}$ & 4.3 & 69 & 10 & $90 \mathrm{a}$ & 0.9 & 51 \\
\hline MSD $^{x}$ & & & 1.4 & 37 & & & 1.4 & 37 & & & 1.6 & 12 \\
\hline
\end{tabular}

${ }^{2}$ Letters indicate differences in percent alive within a column, based on contingency tables $(P \leq 0.01)$.

${ }^{\mathrm{y}}$ Bacterial canker rated on a scale of 0 to 5 , where $0=$ none and $5=$ dead.

${ }^{\times}$Waller-Duncan minimum significant difference $(\mathrm{k}$ ratio $=100)$.

at Byron, Ga., and at Elgin (near Columbia), S.C. (Table 1) (Okie et al., 1994). In ongoing field trials at Elgin and Byron, using commercial scion cultivars, more trees budded on seedlings of BY520-9 have survived than those on Lovell or Nemaguard seedlings (Table 2). Seedlings of BY520-9 are moderately susceptible to Clitocybe root rot/Armillaria tabescens (Stop.: Fr.) Dennis], as are Lovell and Nemaguard.

Greenhouse screening indicates seedlings of BY520-9 are good hosts for C. xenoplax, similar to seedlings of Lovell. Greenhouse tests show at least some of the parental selections have seedlings that are as resistant as Nemaguard to $M$. incognita (Table 3) and $M$. javanica.

Commercial cultivars on BY520-9 seedlings are vigorous, as judged by trunk crosssectional area, and productive after 4 years in commercial trial (Table 2). Long-term productivity is not yet known. BY520-9 seed is
Table 3. Host suitability of seedlings of three peach rootstocks and tomato to Meloidogyne incognita when grown in the greenhouse for 56 days. Means of six replications, except for BY520-9 (five replications) and tomato (one replication).

\begin{tabular}{lcc}
\hline \hline Rootstock & $\begin{array}{c}\text { M. incognita (egg } \\
\text { masses/root system) }\end{array}$ & $\begin{array}{r}\text { Host } \\
\text { rating }\end{array}$ \\
\hline Lovell & 56 & 4 \\
Nemaguard & 0.2 & 1 \\
BY520-9 & 0.2 & 1 \\
Rutgers tomato & $100+$ & 5
\end{tabular}

${ }^{2}$ Host rating: $0=$ no egg masses; $1=$ one to two egg masses; $2=$ three to $10 \mathrm{egg}$ masses; $3=11$ to $30 \mathrm{egg}$ masses; $4=31$ to 100 egg masses; and $5=100+$ egg masses. Ratings $\geq 3$ are considered suitable hosts.

(Over the next 5 years, seed supplies of BY520-9 will increase, allowing broader cornmercial testing by nurseries and growers. The USDA and Clemson Univ. have applied for a Plant Variety Protection Certificate for BY520-9. During this time, individual selections will be compared as seed parents. It is anticipated that ultimately a single selection will be made, named, and released. The bulked seed of BY520-9 will likely be withdrawn as seed of the new selection becomes available. For information about obtaining seed of BY520-9, contact authors T.G. B. or G.L.R.)

\section{Literature Cited}

Lownsberry,B.F.,E.F. Serr, and C.J. Hansen. 1959. Deciduousfruitandnuttrees.Calif. Agr. 13:1920.

Nyczepir, A.P., E.I. Zehr, S.A. Lewis, and D.C. Harshman. 1983. Short life of peach trees induced by Criconemella xenoplax. Plant Dis. 67:507-508.

Okie, W.R., G.L. Reighard, T.G. Beckman, A.P. Nyczepir, C.C. Reilly, E.I. Zehr, W.C. Newall, Jr.,andD.W.Cain.1994.Field-screening Prunus forlongevity in the southeastern United States. HortScience 29:673-677.

Ritchie, D.F. and C.N. Clayton. 1981. Peach tree short life: A complex of interacting factors. Plant Dis. 65:462-469.

Werner, D.J., P.R. Fantz, and J.C. Raulston. 1985 'WhiteGlory'weeping nectarine. HortScience 20:308-309. 